\title{
LA CONQUISTA ESPIRITUAL DE LAS CALIFORNIAS. UN ENSAYO DE SUS PRINCIPALES PARADIGMAS
}

\author{
Por \\ Felipe I. Echenique March*
}

\begin{abstract}
RESUMEN
En contra de lo que suele suponerse y después de una extensa investigación y reflexión, el autor analiza en este artículo cómo la llamada "conquista espiritual" de la California no fue armoniosa y del todo bien intencionada. Algunas comunidades indígenas de la península, así como en otros lugares de América, quisieron liberarse de los impostores y se rebelaron utilizando la fuerza. Ante esto la respuesta fue un contraataque cuya finalidad era someterlos nuevamente a las normas introducidas desde el viejo mundo.

En algunos casos, como en la porción meridional, los métodos para controlarlos tuvieron como resultado el aniquilamiento de pueblos enteros.
\end{abstract}

\begin{abstract}
Against what is thought and after an extensive investigation and reflexion, Felipe Echenique analizes in this article how the so called "spiritual conquest" of California was not harmonious and well intentioned. Some comunities, as in other parts of America, wanted to liberate themselves from the impostors and rebelled using force. The answer was a counterattack which objective was to submit them to the norms introduced from the Old World.

In some cases such as in the Southern portion of the peninsula, the methods to control them had as a result the annihilation of entire societies.
\end{abstract}

\section{PREÁMBULO}

Desde los inicios de la conquista de América, las órdenes religiosas quisieron mostrar al monarca y a las huestes militares que ellos eran una alternativa, menos violenta y más adecuada; para llevar a cabo la integración de esa "nueva humanidad" al naciente sistema colonial. Tal argumento fue esgrimido cada vez más insistentemente conforme se

\footnotetext{
- Licenciado en historia por la Universidad Nacional Autónoma de México. Actualmente es investigador de la Dirección de Estudios Históricos del Instituto Nacional de Antropología e Historia.
} 
pretendía expandir la frontera norte de lo que se dio por llamar la Audiencia de México. Habitantes y territorios de aquellas regiones septentrionales poco se parecían a los que habían quedado englobados en la Nueva España nuclear. La misión y el presidio fueron, pues, las instituciones que deberian encargarse de la conquista de los diversos grupos étnicos que poblaban y dominaban el amplísimo Septenurión novohispano y donde, obviamente, quedaba incluido el mítico reino de Las Californias.

\section{¿Un hecho aislado o muchos problemas de interpretación y ubicación?}

"¿Para qué me llevan? No me lleven. Mátenme a mí también $y$ váyanse" (Taraval, citado en Del Rio, 1984:223).

Tales palabras, pronunciadas por uno de los cabecillas guaycura o pericúe durante los interrogatorios que siguieron a lo que se considera como la mayor de las rebeliones en la península Californiana, la de 1734, podrian interpretarse de dos maneras. Por un lado, puede presumirse que el dolor y la desesperación que trasmiten obedecían a la intención del escritor de mantener la dramatización de aquel evento. Por otra parte, y si lo anterior no fuese cierto, nos estaría mostrando, sin lugar a dudas, la desesperación a que habían llegado aquellas comunidades de guaycuras y pericúes, en el extremo sur de la península de California, que se revelaban al nuevo orden y concierto impuesto por los hijos de San Ignacio de Loyola. Su vida, la del cabecilla, ya no era importante ni para él mismo, ya que la ofrendaba a cambio de que los conquistadores abandonaran sus territorios.

Si lo anterior fuese cierto, entonces, aquellas palabras vendrían ha contradecir lo escrito por los jesuitas e incluso por la historiografía que ha seguido la llamada gesta evangelizadora de las Californias, en cuanto a que la conquista espiritual en aquella basta lengua de tierra se realizo: rápidamente, sin oposición y sin violencia; debido sobre todo al amor y sacrificio de los misioneros para con los nativos y que por lo tanto aquella sublevación no fue más que un hecho aislado.

Después de un largo proceso de investigación y reflexión, he llegado a creer que la llamada "conquista espiritual" no se realizó en forma rápida, sin oposición y sin violencia, que las comunidades de una u otra manera y dependiendo de sus posibilidades y experiencias historicas, se resistieron a dicha conquista, la cual utilizo distintos métodos violentos para sujetar y controlar a las comunidades de aborígenes llegando incluso al extremo de su aniquilamiento, siendo aquella sublevación de 1734, el punto más álgido de las manifestaciones de rechazo y resistencia, por lo menos en la zona más meridional de la península. 
Demostrar lo anterior, contra lo que suele suponerse, no es fácil porque, además de requerirse de una extensa investigación y reflexión, es necesario una pormenorizada exposición que paso a paso vaya mostrando los paradigmas existentes, su discusión y los posibles nuevos planteamientos, manteniendo una estrecha y puntual relación con el material documental de apoyo a fin de que no haya lugar a dudas, de lo que ahora se expone como discusión y discurso no sea ni parezca producto de una invensión o, en su defecto, de una diatriba ideologizante, sino justamente resultado de la revisión crítica del llamado material de primera mano. Bajo el reto enunciado, se intenta desarrollar la exposición del presente trabajo.

\section{LA HISTORIOGRAFÍA JESUÍTICA Y PROJESUÍTICA SUS PARADIGMAS Y SU DISCUSIÓN}

Así, lo primero que bemos de decir es que resulta más o menos fácil trazar la línea de continuidad de la historiografía que ahora criticamos y cuyos paradigmas básicos han quedado enunciados en párrafos anteriores.

Sin duda, para el caso que aquí nos ocupa, el antecedente primario de esa historiografía se remonta a la obra del jesuita Andrés Pérez de Ribas. donde expone desde el comienzo:

Era Sinaloa una selva de fieras, una cueva de demonios, donde habitaban millares de hechiceros. Era un monte espeso de breñas, un eriazo donde no nacía planta que diese fruto, sino espinas y abrojos. Era peor que un Egipto, cubierto de tinieblas palpables. Pero con todo no se olvidó Dios de los desiertos despoblados que dijimos (Pérez de Ribas, 1992:33).

Y para mostrar que Dios no había olvidado a estos gentiles - dice Pérez de Ribas - éste enviaba ahora a los jesuitas para mostrarles "los medios con que la divina sabiduría les encamine la luz del evangelio", para rehacer y corregir su infausta vida y con ello alcanzar la gloria de la vida eterna. (Pérez de Ribas, 1992:xuII).

Dichos medios de salvación, como queda expresado, eran los propios jesuitas porque poseían los conocimientos y prácticas de la renovada vida cristiana, que para el caso que aquí nos ocupa consistía, como decía Pérez de Ribas, no sólo en predicar la palabra de Dios y hacer cumplir sus preceptos, sino también en proscribir las armas y las astucias alevosas, que tanto daño habían ocasionado entre aquellos gentiles, si bien no dejo de reconocer que el uso de aquellas armas seglares debían utilizarse cuando se viesen "obligados de ellas, y con muy justa causa" (Pérez de Ribas, 1992:534), 
Así, la prédica de la palabra de Dios y el ejemplo caritativo y bondadoso que darían los santos barones de la orden de San Ignacio se contrapondría a las prácticas y ejemplos que daban las huestes conquistadoras laicas y civiles, cuyos resultados - decian los jesuitas - habían sido y seguían siendo funestos para el sistema imperial y para la gloria de Dios.

Aquella propuesta pareciera ser ratificada por el padre Eusebio Francisco Kino cuando éste escribió el 20 de abril de 1683 una carta al padre Francisco Castro, durante los primeros meses en que estuvo en las costas de la península Californiana. En ella decía:

Estos guaycuros del puerto de $\mathrm{La} \mathrm{Paz}$, aunque hasta los fines de junio estuvimos con mucha paz con ellos y nos venían a ver casi todos los días trayéndonos fruta y pescado..., después que se les prendió uno de ellos y se les mataron diez o once personas de las más principales con un tiro de un pedrero aqui ya no ros venían a ver ni teníamos esperanza de que en muchos meses habían de olvidarse del daño que de nuestras armas babían recibido... por eso paso a suplicar a vuestra reverencia que por amor de Dios... negocie, haga y alcance con el señor virrey... que manden que esta conquista se procure hacer con paz y amor y no con demasiado rigor de las armas, pues con los rigores se huyen los indios y se retiran y desamparan en los montes, cuando con la paz y agasajo y caridad cristiana acudirán muchisimas almas a hacer cuanto les enseñamos y quisiéremos... (Bayle, 1933:18).

Y como si esas palabras se hubiesen cumplido a cabalidad, se prosiguí escribiendo y narrando "la proeza" de la conquista espiritual de las Californias, como no violenta, sin oposición, rápida y eficaz. Citemos algunos ejemplos para mostrar lo anterior. Salvatierra escribirfa:

Llegaron a la ensenada de las Palmas y los vecinos de sus rancherías se mostraron como en otras partes esquivos y desconfiados; los padres que conocían muy bien el genio pueril de aquella gente, con algunos donecillos y caricias los fueron amansando hasta conseguir que oyesen con gusto la doctrina cristiana y a competencia empezaron a ofrecer sus párvulos al bautismo. ${ }^{1}$ (Salvatierra, 1857:182).

\footnotetext{
1 Para otro caso puede verse el "Informe y relación sucinta que de la nueva conversión, estado y progresos de la California, hizo y presentó a la Real Audiencia de Guadalajara, pox su orden el padre Francisco María Piccolo de la compatía de Jesús".
}

Digo, seffor, que al presente es muy feliz, y que tan buen principio da buenas esperanzas de la reducción a nuestra santa fe de tan dilatado reino. Como empresa tan gloriosa ha sido más del cielo que de la tierra, más de María Santisima que de 
El Padre Rodero, por su parte, en su informe sobre las Californias en 1737 escribio:

Corrió la fama de esta novedad [la llegada de los misioneros y su hueste militar] por lo interior de aquella tierra [la Península de California], y los que, con armas, no se pudieron sujetar [se entiende que se está refiriendo a los anteriores intentos], voluntariamente rendían sus cuellos al yugo suave de la fe de Cristo, y se sujetaban a los ministros de Dios que, con tanto amor, celo y desinterés, buscaban el bien y remedio de sus almas; sin que, habiéndose extendido la noticia de los extranjeros entre aquellos bárbaros, hubiese nación, o parte de ella que tomase las armas o inquietase la nueva conquista, quedando, por este medio, aquel país agregado por los jesuitas al dominio de vuestra majestad, sin costo alguno, ni un solo real, de los Reales Haberes (Piccolo, 1962:286).

Innecesario sería llenar este trabajo de citas que refiriesen lo dicho y expuesto por los jesuitas, de modo que podemos incluso dar un gran salto en la larga cadena de estas expresiones y vayamos a lo escrito por Ignacio del Río, autor contemporáneo que se ha ocupado de estos temas, y que, sin temor a equivocarnos, podemos decir que es el académico de nuestros días que más tiempo y trabajo ha dedicado a lo que llama proceso de aculturación en las Californias y que, en última instancia, sus textos vendrían

unos pobres religiosos, era forzoso que le acompañara la felicidad. Con tan poderoso brazo pudimos ser instrumento de sus prodigios; porque, fiados en su patrocinio, pasamos el mar que, por aquella, parte divide estos reinos de la California, llevando por norte de nuestra navegación a aquesta estrella del mar, en la devotísima imagen de la Señora de Loreto, que, con prosperidad, nos pusoen el deseado puerto; en donde, colocada luego con la mayor decencia que nos pudo permitir el país y nuestra cortedad, pusimos en sus manos la empressa, para que, como suya, corriera por su cuenta; para que la que había sido tan favorable estrella del mar, en nuestra navegación, fuera, en la tierra de Californias. Benéfico sol que, con la luz de su intercessión, desterrara las tinieblas de la infidelidad que cegaban a los que vivían en las sombras de la muerte (Piccolo, 1962:46).

Gerard Decorme en su trabajo La obra de los jesuitas mexicanos, durante la epoca colonial (1572-1767), (1941) escribió:

Luego que alguna tribu aceptaba convertirse y consentía en reunirse en pueblo, se construía una iglesia, choza para el misionero y las familias y se empezaba la labranza que había de sustentar la nueva comunidad... La enseñanza era rudimentaria, como el compendio del P. Castaño que virtieron en sus lenguas: la existencia e unicidad de Dios, sus mandamientos para lograr el cielo y evitar el infierno, los sacramentos y las oraciones, la devoción a la Eucaristía y a la Virgen, la misa al menos semanal y las prácticas de la semana santa... Es para nosotros un milagro, que prueba la trascendencia de la ley cristiana, ver la transformación pronta y radical que obraba el bautismo en indios antropófagos, asesinos, polígamos, borrachos, ladrones, hechiceros y enemigos a muerte de indios de otras razas. 
a ser la mejor síntesis, o al menos la más reciente, que hasta ahora se ha escrito sobre el proceso de conquista en las Californias. Así pues Ignacio delRío, siguiendo a Powell y a otros tantos historiadores, dice por ejemplo:

Se advirtió desde entonces [los primeros días de la conquista] que tales grupos [los cazadores recolectores] resultaban, por su mismo nomadismo, extremadamente elusivos y difíciles de someter por la vía de la conquista militar, mientras que por lo común no ofrecían mayor resistencia al contacto cuando el español, en vez de acosarlos militarmente, procuraba atraerlos sin provocar enfrentamientos innecesarios y estimularlos mediante dádivas diversas, particularmente de bienes de consumo inmediato, para que-no tendieran a buir y se conservaran de paz. Los métodos de reducción empleados por los misioneros de las varias órdenes religiosas que actuaron en el norte novohispano se fundaron en el principio de que aun los grupos tenidos por más bárbaros y belicosos deponían su actitud bostil y cedían al influjo misionero cuando se les trataba con suavidad y se les obsequiaba adecuadamente (Del Río, 1984:84).

\section{Veamos otro pasaje del mismo autor:}

Pero es evidente que uno de sus mayores cuidados [se refiere a los jesuitas] fue el de, en lo posible, no hacer descansar la conquista en la acción militar directa. Con la ostentación que a veces se hacía del poder de las armas de fuego lo que se buscaba precisamente era no tener que usarlas en combates frontales con la población indígena. Los

No se puede negar que, para los nif̃os y jóvenes (aún no degradados), tenía la vida cristiana y civilizada atractivos irresistibles. El amor y trato dulce de sus misioneros (que superaba al de sus propios padres), los halagas y fiestas con los que los combidaban los cristianos, el poder salir y viajar fuera de sus fronteras sin peligro de muerte, el hallar hermanos en las otras tribus, el ver las iglesias y casas que eran la gran novedad y gloria de los pueblos vecinos, el pacífico cultivo de sus campos y el sustento asegurado, la felicidad de las familias, la variedad y exterioridad de las fiestas religiosas y profanas (pues se guardó o cristianizó todo uso o juego compatible con su nueva vida), la defensa contra injustos agresores aun españoles y otras muchas ventajas que bien merecen los sacrificios que tenian que hacer para renunciar su misera libertad.

Por su parte Pablo L. Martínez en su Historia de Baja Califormia (1991:256), terminó escribiendo:

Es cierto que el indio, en favor del cual se intentaba la conquista, salió perdiendo con Ésta, puesto que con ella empezó a caminar rápidamente a su extinción; pero esto no fue culpa de los jesuitas, sino de la violencia con que trató de exigirse a la naturaleza humana de los californios un cambio de vida física y mental. La naturaleza no da salto, dice un proloquio latino; y esto está probado plenamente en el caso de nuestros indígenas peninsulares. Los mató el contacto con la cultura y las costumbres, con las enfermedades y con los vicios de los blancos. 
padres se esforzaban por convencer a los indios de que no estaba en su ánimo bacerles una guerra ofensiva y que llevaban gente armada tan sólo como medida de protección. Preguntado el padre Clemente Guillén por ciertos Guaycuras que si tenía el propósito de pelear con ellos, respondió el misionero que los españoles no babrian de combatir sino con quienes les quisieran "hacer graves daños". Píccolo se cuidaba de no llegar de noche a los parajes donde se suponía que había indios acampados, para que éstos no se asustaran con la presencia de extraños y sospecharan que se pretendía infligirles algún mal (Del Río, 1984:88).

Así pues, con estos párrafos queda mostrado como, de una u otra manera, se continuó el discurso jesuita que señalaba la conquista espiritual como una obra no violenta y consecuentemente sin oposición y resistencia de las comunidades de aborígenes.

Bajo tales preceptos, era y es lógico que las rebeliones indígenas que se sucedieron en las Califomias, no fuesen o sean claramente entendidas y cuyas causas fuesen buscadas en fenómenos sobrenaturales o en otro tipo de explicaciones, como lo hiciera Rodero a nuestros actuales historiadores. Por ejemplo Rodero escribió con respecto a la rebelión de 1734:

La recién convertida [nación] Guaycura y Pericúes, engañados del común enemigo por medio de hechiceros que los aterraban, con amenazas, en nombre de las fingidas deidades que, en su gentilidad, adoraban; $\mathrm{y}$ por volver a sus antiguas bárbaras costumbres $\mathrm{y}$ libertad, sacudiendo el suave yugo de nuestra Santa Ley, se revelaron inopinadamente, $\mathrm{y}$ acometieron a las misiones en que estaban los padres Lorenzo Joseph Carranco y Nicolás Tamaral, quitaron la vida al primero, en principios de octubre de 1734, y al segundo el día 3 de dicho mes. Y no saciando su furor con haberles muerto, quemaron sus cadáveres $\mathrm{y}$, juntó con ellos, todos los santos y omamentos sagrados de las iglesias; $y$ pasando al pueblo inmediato, emplearon su furia on la iglesia, reduciendo a cenizas cuanto en ella había de sagrado (Rodero en Píccolo, 1962:295-296).

\section{Por su parte el historiador Ignacio del Río señalaría:}

La rebelión indígena más importante de la época jesuítica, tanto por su magnitud como por sus consecuencias inmediatas y mediatas, es la que se produjo el año de 1734 en la región del sur. El foco del movimiento se localizó en la misión de Santiago y San José del Cabo, pero la rebelión terminó por extenderse hacia las otras dos misiones sureñas: la de Nuestra Señora del Pilar de la Paz y la de Todos Santos. Se trató de un movimiento que duró realmente poco tiempo, pues en menos de tres semanas la población rebelde arrasó prácticamente las 
cuatro misiones y se enseñoreó de tođa la región meridional de la península. Fue el único caso en que los aborígenes penínsulares, puestos en pie de guerra, lograron recuperar, aunque transitoriamente, el dominio completo de una extensión territorial que había sido ya objeto de ocupación por parte de los misioneros y sus acompañantes... Hay evidencias claras de que el movimiento tuvo sus orígenes en el conflicto cultural y de que los sublevados pretendieron poner término a la situación de contacto con el objeto de que sus tradiciones de vida no se vieran ya perturbadas por la política misionera y el irresistible influjo de los enclaves misionales. Ciertas declaraciones atribuidas a presuntos rebeldes capturados así lo dejan ver. Se dice que unos declararon que habían victimado a su ministro "porque no les dejaba bacer lo que querían y prohibía que tuviesen muchas mujeres". El padre Nápoli aseguró que todos los indios que fueron interrogados a este respecto dijeron que los misioneros habian sido muertos porque no consentían en sus neófitos, "después de bautizados, la multiplicidad de mujeres", y porque obligaban a los indios a "rezar y venir a misa" ${ }^{2}$ (Del Río, 1984:210-211).

En la primera referencia no hallamos una explicación razonada, sino la expresión de un sentimiento y una muy particular apreciación de los hechos, que tenía que ver más con la propaganda publicitaria de la campaña jesuita y de los obstáculos que la orden hallaba para seguir adelante. La segunda referencia, intenta secularizar, con base en lo dicho por los propios misioneros, el discurso ignaciano en cuanto a que dicha rebelión tuvo su principal motivo en el propósito de los naturales a volver a sus antiguos usos y costumbres, sobre todo en relación con el restablecimiento de la poligamia. De modo que quisieran aclararse los motivos, pero como no se va más allá del propio discurso jesuítico, no se avanza mucho en este punto $y$, por lo tanto, se repiten, matizándolos, los mismos argumentos en cuanto que los guaycuras y pericúes eran los "más insumisos", "rebeldes" y "bárbaros" de todos los californios y a quienes sólo les complacía vivir "en el cieno de la incontinencia", según aseguraba Nicolás Tamaral y como han seguido repitiendo muchos estudiosos.

Repetir las "viejas" causas de la sublevación como elementos explicativos impide agregar algo nuevo a nuestro saber, más aún: impide articular los resultados de investigaciones modernas y contemporáneas (en antropología, etnología, etcétera) al conjunto de la investigación historiográfica, manteniendo el conjunto de prejuicios que sobre aquellas comunidades

2 Referencias similares, aunque más extensas, pueden verse en Francisco Javier Alegre (1960:363-425), Gerard Decorme (1941:522-528) y Pablo L. Martínez (1991:217-228). 
inculcaron los jesuitas apoyados en el contexto de una época y una cultura determinadas, puestas sobre el fondo de un proceso de dominación y conquista.

Lo que resultaría verdaderamente ilustrativo sería seguir en detalle no solamente esa sublevación, sino "todas las otras" surgidas en el extenso territorio californiano con las correspondientes reacciones de todos los elementos dominadores que, naturalmente no representan de ninguna manera un factor pasivo. Ante todo, fueron respuestas extremas ante la conquista, subordinación y destrucción completa de las formas de vida y organización prehispánicas de las comunidades, y muy probablemente dichas manifestaciones extremas de violencia sólo aparecieron después de que las comunidades acumularon experiencias de resistencia y enfrentamientos diversos, donde quizá la propia violencia que ejercieron los conquistadores fue asimilada por las comunidades y volcada sobre sus maestros.

Así pues, repetir lo dicho por los jesuitas no lleva a ningún lugar, sino a seguir dando vueltas sobre lo que dijeron y afirmaron ellos mismos, sin aportar nada nuevo, sin tomar una distancia crítica frente a ese discurso.

Pensamos que el seguimiento en detalle de las batallas y enfrentamientos de los conquistadores con las distintas comunidades que poblaban y dominaban aquel territorio, permitirá no sólo precisar las distintas formas concretas en que se opusieron y resistieron aquellas comunidades, sino también exhibida la naturaleza histórica de las respuestas extremas de los aborígenes, no como el producto espontáneo y más o menos arbitrario, sino como la secuela histórica de un movimiento constante de resistencia, con lo cual los prejuicios quedarán exhibidos y así anulados.

Así pues, to que nos hace falta son las historias de estas sucesivas conquistas y la diversidad de las formas de resistencia que adoptaron ante ellas las propias comunidades. Eso es lo que está por escribirse, alejándonos así de las "explicaciones" que no van más allá de los mitos y visiones voluntaristas o fatalistas, por lo demás muy a la mano, donde la fácil y rápida aceptación de la cultura occidental se exhibe como la mejor muestra de la superioridad irrefutable de la misma (sin parámetros precisos) y con lo cual se relativiza y simplifica al máximo los distintos pasos y momentos violentos que siguió la llamada conquista espiritual y su contraparte, las actitudes que asumieron las distintas comunidades de naturales ante los conquistadores.

Pero aun antes de que podamos entrar de lleno en el desarrollo de nuestras historias, es menester detenemos en la exposición y análisis de algunos "paradigmas" que han servido de sustento a la historiografía de la "conquista espiritual de las Californias" y que deben ser desentrañados 
para observar la lógica del discurso que ha convencido a ne6fitos y especialistas. Hemos de decir que dichos paradigmas están imbricados y Iogicamente relacionados, si bien dichas operaciones pierden su grado de certeza ante la contundencia de la contrastación crítica de los propios materiales documentales que les sirvieron de sustento.

Uno de los principales paradigmas que ha servido para apoyar otros más, ha sido el de la pobreza extrema tanto material como espiritual de los llamados californios, con que ya antes habían sido etiquetadas los diversos grupos étnicos del llamado territorio californiano. ${ }^{3}$

Esa pobreza extrema de los californios se pone inmediatamente en dos niveles no opuestos, sino complementarios e interactuantes, que se derivan de dos corolarios estimados como logicos y naturales. El primero se refiere a un estado permanente de hambre y el segundo a un estado permanente de nomadismo.

Estos dos corolarios, ya dispuestos como realidad de fondo, explicarian en buena medida el que las comunidades asistiesen a las misiones debido a que allf encontraban los alimentos necesarios para su subsistencia, proporcionados por los misioneros en forma de regalos. Se concluye de lo anterior que esa atracción propició el contacto y subsecuentes momentos de aculturación sin que se haya violentado mayormente la vida comunal y sin que las comunidades hayan manifestado mayor rechazo o resistencia a la conquista espiritual. Así pues, se echa mano de criterios apriorísticos que permiten redondear un discurso con apariencia lógica en detrimento de una dinámica histórica siempre problemática y por lo demás no esclarecida; esto es, que no refleje necesariamente el proceso mismo de conquista.

Es probable que esa lógica del discurso impuesto por los primeros jesuitas que refirieron las obras de sus hermanos de orden hayan terminado

3 Paul Kirchhoff, en la introducción que hizo a la obra de Baegert, no quedo fuera de este influjo al referir:

La extrema fragmentación de la vida social de estos indios [los Guaicuras de la misión de San Luis], descrita por Baegert en colores tan sombríos y al mismo tiempo tan fuertes, con seguridad no nos da la imagen de una tribu "primitiva" en el sentido de un grupo todavía muy cercano a la vida de los primeros verdaderos hombres, sino, muy al contrario, de una tribu con una historia tan larga como la de muchos otros grupos más afortunados, pero que careció de todos aquellos estímulos y oportunidades que a éstos permitieron subir en su evolución de escalón en escalón. Los Guaicuras de Baegert, desde cierto momento de su historia en adelante, no sólo no siguieron subiendo, sino, por la lógica de los procesos hístóricos que a ningún pueblo permiten quedarse más de un breve momento en el mismo punto de su evolución, comenzaron a bajar y seguir bajando cuando nuestro autor tos conoció (Baegert, 1942:xxxvi-xxxvi1). 
convenciendo a néfitos y especialistas. Veamos un ejemplo diáfano de lo que decimos citando de nuevo a Del Río:

La práctica de repartir alimentos en las misiones para atraer a los indios y mantenerlos por algún tiempo como sujetos de catequización tenía la ventaja de ser un método de reducción que se activaba, entre otros factores, por los propios intereses que se despertaban en los catecúmenos. En la interpretación jesuítica, esos regalos aparecen referidos como actos de beneficencia y caridad que respondian primordialmente a un imperativo moral del cristianismo y que, por ser intrínsecamente buenos, no podian sino dar lugar a una respuesta indígena, igualmente positiva, de gratitud y espontáneo sometimiento al orden misional. Servirse de un medio como ese, "que amansa y domestica a las bestias más bravas", apunta Venegas, fue lo que permitió al padre Salvatierra doblegar suavemente a quienes "habían vivido en su gentilidad más como bestias montaraces que como hombres racionales", hasta llegar a "convertirlos de lobos en mansos corderos" (1984:131).

Se observa aquí como ha llegado hasta nuestros días la tradición historiografica jesuítica en cuanto a la manera en que queria que se viese, por una parte, a los aborígenes y, por la otra, el surgimiento y continuidad de las instituciones que ellos pusieron en práctica, sin dar un paso más allá de lo expresado por los jesuitas que comenzaron a contar la gesta de sus compañeros de orden. No se interroga acerca de la realidad prehispánica y mucho menos se revisa más detenidamente el conjunto de escritos que dejaron los primeros misioneros, como Kino y Salvatierra, que es donde se describen los pasos dados para la conquista de aquellas comunidades y que, en muchos casos, contrasta con lo que después se escribiría sobre esos mismos hechos. Detengámonos, pues, en las siguientes páginas para mostrar el establecimiento de dicho paradigma y su consecución y proyección, y añadamos finalmente una reflexión critica en torno a la confrontación de la información que proporcionaron los informes jesuitas.

Es muy probable que el argumento de la miseria espiritual y material de los aborigenes llamados genéricamente californios se haya comenzado a desprender de aquella afirmación del padre Píccolo:

Como los indios sólo se sustentaban de raíces y frutos silvestres que buscaban por los montes para poderlos adoctrinar determinó el padre Salvatierra que todos los días se repartiese maiz cocido y atole a todos los que asistían a la doctrina; y esta práctica fue general en todas las misiones. El mismo padre Juan María iba a cortar la leña al monte, la traía cargada al real, asistía al fogón y repartía cariñosamente un cucharón a cada uno de los hijos (Píccolo, 1962:101). 
Queda claro que los naturales asistran a la doctrina por la ración de comida que les daba el mísionero, y la anterior afirmación descansa en el hecho de que "los indios sólo se sustentaban de raíces y frutos silvestres que buscaban por los montes". En esta referencia el hecho de causalidad parece neutro ya que no se califica el que los naturales se sustentasen de raíces y frutos; no obstante, comienza a abrirse la posibilidad de enjuiciar las formas de sustento de los naturales. A lo largo de los textos de Piccolo, este hecho de causalidad no va más allá e incluso podemos decir que las líneas anteriores, más que con la descripción o enjuiciamiento de los naturales, tenía que ver con la apología dirigida a su compañero de orden, el padre Salvatierra, con todo lo que ello representaba.

Pero este resquicio abierto por Piccolo en las formas de la alimentación de los naturales fue tomándose en negativo y efectivamente aprovechada, hasta llegar al punto en que se acepta, sin miramiento alguno, que, antes de la llegada de la orden, las comunidades casi se morian de hambre. Muchos estudiosos de aquella conquista han resaltado las líneas escritas por Baegert y que hizo famoso aquello de que:

... los califormios que buscan su sustento en el mar, (de ellos hay pocos, porque también esto tiene sus dificultades), se ven forzados a sufrir hambres negras o enfrentarse a una escasez espantosa. Tienen que buscar y devorar toda clase de inmundicias como si fuesen bocados exquisitos, y permanecer durante todo el año en involuntaria holgazaneria (Baegert, 1942:32).

Esto fue aun ampliado y difundido por Francisco Javier Clavijero, quien escribió lo siguiente:

Comían, y aún comen al presente a causa de su miseria muchas cosas que para nosotros no son comestibles, como raíces y frutas muy amargas o insípidas, gusanos, arañas, langostas, lagartijas, culebras, gatos y leones y hasta pieles secas. Un perro es para ellos tan apreciable como para nosotros un cabrito. Pero jamás los obligó su hambre a alimentarse de carne humana, y aún se abstuvieron siempre de comer tejón porque les pareció semejante al hombre.

En sus comidas hacen cosas verdaderamente extrañas. En el tiempo de la cosecha de las pitahayas comen hasta hartarse; más para volver a usar de ellas después de haberlas comido y digerido, no desechan sus deposiciones, sino que de aquello que antes fue pitahaya separan con indecible paciencia los pequeñísimos granos de la fruta que quedan sin digerirse, los tuestan, los muelen y reducidos a harina los conservan para comerlos después en el inviemo. Algunos españoles dan a estas operaciones el nombre burlesco de segunda cosecha de pitahayas. 
Los bárbaros que habitan en la parte septentrional de la península, ban hallado el secreto, ignorado del común de los mortales, de comer y volver a comer repetidas veces un mismo manjar. Ligan bien con una cuerda un bocado de carne seca y endurecida al sol, y después de haberle mascado un poco le tragan, dejando la cuerda pendiente de la boca; pasados dos o tres minutos le vuelven a sacar por medio de la cuerda para mascarle de nuevo, y repiten esta operación tantas veces cuantas son necesarias para consumir aquel bocado o ablandarle de modo que no puede ya estar atado. Al extraerle del esófago hacen tal ruido, que a quien nunca les ha oído le parece que van a ahogarse.

Cuando comen de esta manera muchos individuos juntos, lo practican con mayor aparato. Se sientan en el suelo formando un círculo de ocho a diez personas, toma una de ellas el bocado y le traga, y sacándole fuera đespués, se le da a otra, $\mathrm{y}$ ésta a otra; prosiguiendo así por todo el círculo con mucho placer, hasta que el bocado queda consumido. Los españoles que han observado esto se han admirado, y efectivamente, no sería creible si no estuviese atestiguado unánimemente por todos los que han estado en aquel país. Algunos jesuitas que no querían creerlo a pesar de tantas personas graves y sinceras que lo afirmaban, babiendo ido después a la California, lo vieron con sus propios ojos. De entre aquellos indios que han abrazadoel cristianismo se ba ido desterrando este modo de comer tan asqueroso y peligroso en fuerza de las continuas represiones de los misioneros (Clavijero, 1970:54. Subrayado nuestro).

Del Río, sustentándose en la afirmación de los jesuitas, ha escrito lo siguiente:

Sin el conocimiento de la agricultura, los antiguos pobladores de la península vivían dedicados a la recolección, la caza y la pesca. La búsqueda de sustento diario los hacía peregrinar de un sitio a otro para conseguir algún animalejo y para recolectar los elementos de origen vegetal que sabian comestibles, Los indios, que obtenían así apenas lo necesario para conseguir su subsistencia, hubieron de aprovechar los recursos naturales a su alcance de un modo que bien puede calificarse de exhaustivo. Dentro de una economía de apropiación, difícilmente hubiera podido ser mayor el grado de explotación de la naturaleza con fines alimenticios (1984:31).

Comían habitualmente diversas raíces, tallos, hojas, semillas y frutos, con cuyo aprovechamiento lograban a veces mediante recursos que les permitían extraer elementos nutrientes aun de plantas aparentemente nocivas para el hombre (1984:32).

En realidad, los californios conocían más de privaciones que de excesos en cuanto a la alimentación, así que con poco que se les diera 
podían sentirse suficientemente compensados, aunque siempre se hallaban dispuestos a procurar una mayor satisfacción (1984:144).

De estas y otras muchas referencias podrian desprenderse que los habitantes de las llamadas Californias vivían en un nivel de mera subsistencia antes de que los invadieran los españoles, $y$ a ese estado de miseria y atraso se debía precisamente el que las comunidades asistieran a las misiones donde se les daba alimento. Sin embargo, tal descripción y su natural corolario no son del todo exactos; hemos de hacer uso de referencias extensas de los primeros misioneros que apuntan precisamente hacia otros rumbos pues hay que decir que, además de aceptarse implícitamente el enfoque de las descripciones misionales, en cierto modo tardías, se excluyen otros muchos pasajes de los mismos documentos que vienen a refutarlo. Salvatierra, por ejemplo, refiere varios hechos que pueden ser indicativos de una situación diferente: "Y a la doctrina vino poca gente por la mañana, pues estarían ocupados en ceremonias y pésames, prevención de frutas y otras comidas". En otra parte refiere: "Es tanto lo que les da de comer la tierra de sus semillas aun afuera de la pitahaya, que nadie se cansa de ir a pescar, siendo así que más que nunca está llena la mar de pescado" (Salvatierra, 1857:116).

Por su lado, el padre Piccolo señalaría, entre otras muchas referencias similares:

Hay copia de árboles a quienes los chinos, por el conocimiento que tienen de los que bay en su tierra, llaman palo santo. Estos dan para el sustento una frutilla en abundancia y sudan incienso muy bueno, también hay muchos frijoles colorados, que cogen los naturales, y de que bacen gran provisión para comer. Tienen, para este fin, más de catorce géneros de semillas, como es el cáñamo, el alpiste, etc. De lo mismo les sirven las raíces. Hay grande abundancia de Yuca, que es su pan cotidiano. Hay camotes muy buenos y dulces. Y apenas hay raíz de plantas y árboles de que no saquen mantenimiento.

Para que no les faltara a los Californios el dulce que, con tantos artificios y trabajo, se hace por acá, les provee el cielo de él en abundancia en los meses de abril, mayo y junio, en el rocío que cae, por este tiempo, en las hojas anchas de los carrizos, donde se cuaja y endurece. Cogen mucho de él; lo he visto yo y comido. En el gusto tienen las dulzuras del azúcar, y sólo se diferencia en el viso, que lo bace obscuro.

También hay abundancia de parras silvestres, hacia los ríos, como queda dícho. $\mathrm{Y}$ en los ríos hay pescado y camarón que cogen,.. tienen también mucha abundancia de jícamas, mejores en el gusto que las nuestras. De todos estos frutos que por sí lleva la tierra, se conoce su 
gran fertilidad, y mejor se reconoce por los frutos de esta tierra que los ha recibido y vuelto con extraordinario logro (Piccolo, 1962:59-61).

\section{Y en otra parte refiere Piccolo para nuestra admiración que los natu-} rales de la sierra:

Tiene higos silvestres en abundancia; muchos mescales, aunque chicos, medesa y macabá, que bay bosques, y cada árbol rendía para familia. De este como frijol tiemo y sabroso, iban comiendo por el camino. No tenían compasión; llevaban sus semillas; en cada parte que parábamos, hallaban metates, ayudaban con las pitahayas y con los hechos del cardón, que llamaban Camamaahua, de cuya semilla hacen mucha cosecha. Por todo el camino, me iban los pobres gentiles cogiendo pitahayas; $y$ luego que llegamos en alguna ranchería, salian con redes los hombres, y las mujeres con bateas de pitahayas, y regalaban a los nuestros con mescales y con sus frutas. En una rancheria, donde estaba algo lejos el agua, salieron los indios con sus bateas llenas, a dar agua a las mulas.

A estos indios ba dado Dios grande abundancia de mescales, pitahayas, y una fruta que llaman los españoles de la otra banda, dátiles. El color y sabor son de dátiles; pero no el hueso, sino una pepitas. Y la planta que los da, no es palma, sino unos árboles como palmitos. Traje unos racimos de dichos dátiles para regalar a mi padre rector y a mi hermano; y no quiso llevarlos Sebastian, porque dijo pesaban mucho (Piccolo, 1962:193).

Por su parte el padre Consang en su viaje por la costa hacía el septentrión Californiano señalaría que cerca de Kañayiakamán, quizá en Kaiavañgua:

Empieza la variedad de mescales, unos muy grandes de que a la vista parecen como los de la otra banda: otros medianos que tienen las pencas y hojas muy gruesas: estos sirven a los naturales en lugar de agua cuando andan fuera de los arroyos; cortan la boja, la calientan, exprimen o chupan el jugo; probé y halle que no es de mal gusto. El tercero es pequeño, y estimado por ser su pan de cada día (Piccolo, 1962:392).

Incluso Baegert, en otra parte de su escrito, reconocía, aunque siempre con ese dejo de mofa e ironía:

El orden de lo que cada día hacían los gentiles, era siempre igual. En la noche, después de llenarse la barriga, solian acostarse o juntarse sentados para platicar hasta cansarse de tanta palabrería o hasta que ya no se les ocurría nada; en la mañana solían dormir hasta que el hambre o su glotonería los obligaba a levantarse, y una vez bien despiertos, reanudaban la tragantona (si es que les quedaba algo del 
día anterior), así como sus risas, pláticas y chistes. Después de esta oración matinal y con el sol bien salido, los hombres agarraban sus arcos y flechas y las mujeres se acomodaban el yugo de la coraza de tortuga sobre la frente. Algunos iban a mano derecha, otros a mano izquierda; por acá seis, por allá cuatro; por acullá ocho o tal vez sólo una pareja, y, en fin, otros más, solitos. En el camino seguían la plática, las risas y los chistes. Se miraba a la redonda para cerciorarse si no quedaba a la vista un ratón, lagartija, serpiente, liebre o venado. Aquí se arrancaba una yuca u otra raíz, allá se cortaba media docena de cabezas de aloe: Luego el grupo descansaba un rato, arrimándose, sentados o acostados, a una sombrita, si acaso la había, pero sin dar descanso a la lengua. Después, se levantaban de nuevo, se jugaba un poco o se entablaba una pequeña lucha para ver quién era el más fuerte o la más fuerte y quién podía derribar a su rival. Más tarde se regresaban por el mismo camino o se seguía adelante por algunas horas más. Se hacía alto donde topaban con agua, se tostaba, quemaba, asaba o molía el botín del día. Se comía en medio de interminables pláticas, mientras quedaba algo o cabía algo en el estómago, y, finalmente, se entregaban al descanso, como el día anterior, platicando sobre cosas infantiles u obscenas. De este modo transcurría un día, un mes y todo un año, y siempre eran la comida, las niñerías, las bagatelas y toda clase de maldades, los temas de sus conversaciones y chismes. $\mathrm{Y}$ hoy día, el ritmo de su vida diaria es casi el mismo, si el misionero no logra imponerse para hacerlos trabajar en las misiones, en labores que de muchas maneras les resultan provechosas (Baegert, 1942:127).

Muchas más referencias podrían citarse no para avalar un estado idilico y de abundancia, sino simplemente para señalar que los naturales de las Californias, o Carolinas como quería Kino, no se morian de hambre antes de que comenzase la invasión novohispana. Tenían la alimentación que sus prácticas, conocimientos y dominio milenario de la naturaleza les permitía. O dicho en otros términos, la alimentación no se obtenía en forma depredatoria como se llega a entender cuando se aplica el término exhaustivo para referir el nivel de explotación de la naturaleza para obtener recursos alimenticios, sino más bien, nosotros pensamos que la producciót de alimentos se sustentaba en una explotación equilibrada de los recurso: naturales que por conocimiento y prácticas, decantadas por generaciones, llegaban a ser la base misma de su sustento. Así pues, por referencias como las que mencionamos podriamos apreciar que la variedad no era reducida, ni escasa y, además, que las prácticas que acompañaban a ciertas comidas no deben ser imputadas a un estado de hambre permanente, sino a la posibilidad de una mala temporada de cosecha de pitahayas o cualquier otro fruto, o escasez de animales de caza, y que ello derivaba, como en 
ahalquier otro grupo humano del orbe, en distintas prácticas con sus urrespondientes ritos y ceremonias como los narrados por Clavijero.

Así, resulta difícil creer que los aborígenes se hayan acercado a las imisiones por la comida que les ofrecían. De modo que tendríamos que huscar otra serie de posibles causas para explicarnos la atracción.

Este hecho tendría que ver, según nosotros, más con los usos y costumbres del mundo prehispánico y con el conjunto de actitudes de los jesuitas después de la conquista de los territorios donde se asentaban las comunidades, y cuyas líneas generales trataremos de esbozar en las siguientes páginas.

Para comenzar, debemos decir que la historiografía se ha detenido muy poco en el análisis y significado prehispánico de las posesiones territoriales de las comunidades que habitaban y dominaban las Californias. Una primera razón de lo anterior podría ser el becho mismo de tener presente aquel derivado del paradigma de la pobreza extrema de las comunidades $y$ que consiste en señalarlas en un estado permanente de nomadismo, como queda ya referido en más de una ocasión hasta aquí. Con ello se inhibe cualquier tipo de búsqueda o reflexión sobre las posesiones territoriales de las comunidades y su dinámica histórica y cultural. Así, mediante una actitud totalmente acrítica, se ha seguido la argumentación de Baegert, cuando señalaba:

No me equivoco grandemente cuando aseguro que la mayoria de estos hombres cambian el lugar de su campamento nocturno más de cien veces al año y no duermen ní tres veces consecutivas en el mismo sitio ni sobre el mismo terreno, con excepción de que pernocten en la misión (1942:79).

\section{Al intentar actualizar esta descripción Del Río señala:}

El mar proveía de alimento seguro y permamente a los grupos "playanos", pero no siempre a las rancherías del interior, las que a menudo se veían impedidas de acceder a las costas debido a los celos con que cada banda, sin excepción de las "playanas", protegían sus territorios de recorrido. Prácticas que se antojan repugnantes, como el de la "segunda cosecha"... (1984:32).

Con todo hemos de decir que se trataba de un nomadismo limitado, ya que los desplazamientos se hacían dentro de una área determinada cuyos linderos se procuraban no transponer so riesgo de que los diversos grupos locales entraran en conflicto, Las guerras entre grupos ocupantes de distintos territorios eran, por lo demás, bastante frecuentes (1984:34). 
Nótese que en la primera referencia el nomadismo es constante e ilimitado, de lo que se infiere la negación de cualquier tipo de adscripción y/o posesión territorial de las comunidades. En la segunda, se excluyen del nomadismo ciertas áreas aceptándose una territorialidad a las commidades, específicamente una posesión prácticamente animal en la cual toda transgresión de parte de las distintas comunidades ocasionaba frecuentes y "repugnantes" prácticas que incluyen guerras entre ellas. No se niega la realidad de los enfrentamientos bélicos, pero en primer lugar habría que señalar en qué consiste ese nomadismo limitado, asfi como los fenomenos que lo ocasionaban y los hechos que pudiesen considerarse como transgresión dentro de una comunidad y que obligaba a las comunidades extrañas a enfrentarse unas con otras.

Sabemos muy poco acerca de lo anterior porque, como ya hemos señalado, las formas de organización territorial prehispánica fueron totalmente ignoradas por los misioneros, sobre todo debido a las posibles implicaciones jurídicas que ello acarrearía y a la propia contravención que a sus esquemas les ocasionaria dicho reconocimiento, pues cuando surge éste - ya en la actualidad - se hace sólo para destacar lo que se considera como la parte negativa, esto es, las transgresiones territoriales, para destacar así el constante estado de guerra que había entre las comunidades antiguas y el corolario de que el cristianismo vino a pacificar. ${ }^{4}$

Asf, para poder analizar la territorialidad entre las diversas comunidades es necesario "escuchar" a los primeros mísioneros, quienes, como hemos dicho, han sido parcialmente leídos en relación con éste y otros muchos aspectos. No nos queda más remedio que recurrir a citas extensas de las fuentes, pues nos parece pertinente debido a un casual y estratégico olvido de las mismas.

Kino refiere desde sus primeras cartas, escritas en Real de Guadalupe, la existencia de lo que él llamó rancherias. Señalaba que "Muchas rancherias destas solían tener 200 ó 300 y 400 y más almas" (Burrus, 1964:296). Piccolo por su parte escribiría:

Son estos californios, por lo que hemos visto y por las noticias de ellos, muchos en las playas más adentro, y mucho más en número por el

\footnotetext{
4 No hay que señalar que lo dicho por Del Río no debe atribuírsele a él mismo ya que Clavijero muchísimo antes que él había escrito: "Cuando los californios eran aún gentiles tenian frecuentes guerras, ya entre dos naciones diversas, ya entre dos o más tribus de una misma nación. El motivo solía sex alguna injuria hecha a un particular, o algún prejuicio causado a una tribu por haber ido otra a pescar, cazar o recoger fruta en los lugares frecuentados por la primera [... A Al cristianismo deben, entre otros beneficios, el de la paz, y el de la caridad, que los ha unido en Jesucristo, haciendo desaparecer del todo sus antiguas discordias" (Del Río, 1984:59, Subrayado nuestro).
} 
norte. Viven en rancherías de veinte, de treinta, de cuarenta y cincuenta familias, pocas más o menos. No usan de casas. La sombra de los árboles les sirve para resistir los bochornos del sol, y las ramas y hojas de los mismos para guarecerse en la noche, contra la inclemencia del tiempo. En el rigor del inviemo viven en unas cuevas que hacen en la tierra; y en todos estos resguardos moran muchos juntos como brutos (1962:64. Subrayado nuestro).

Estas dos anotaciones nos plantean una pregunta fundamental que consistiría en aclarar lo que es una ranchería. Las posibles respuestas podrían sintetizarse en dos: la primera (Baegert y Del Rio), las rancherías cran un conjunto de familias que se movian indistintamente, sin concierto ulguno, dentro de un territorio, para el primero ilimitado y para el segundo restringido. La segunda, las rancherias eran un conjunto de familias cxtensas que acampan temporalmente en sitios estratégicos para de allí salir por las mañanas a surtirse de agua a los manantiales cercanos, cazar, pescar y recolectar frutos; el movimiento de los campamentos estaba dado por los ciclos de la flora y la fauna, fenómenos perfectamente conocidos por las comunidades dentro de territorios prefijados por ellas mismas y que se circunscribían a un área mayor, cuyo uso y explotación correspondía a acuerdos y a una normatividad multisecular entre los distintos clanes que se habian apropiado de territorios especificos. Como veremos más adelante, la primera argumentación no tiene fundamento solido de acuerdo con las primeras informaciones de los propios misioneros, mientras que la segunda está documentada en la misma. Afirma Kino:

Y, a la tarde, [los aborígenes que habían llegado al Real de Guadalupe], se fueron a sus rancherías (Burrus, 1964:194).

El viernes volvieron los indios con una carguita de leña, pues habían visto que el día antecedente habíamos premiado a los que nos habían acarreado leña. A mediodía se volvieron a sus rancherías (Burrus, 1964:196).

Casi en todas partes, hallamos buenas tierras para sembrar, muchos aguajes, lindos valles y llanadas; tres leguas de agua riquísima y ciertas noticias de un río caudaloso que va a la contracosta; muchos y muy grandes mescales, arboledas, tunas, miltomates, guacamotes, muchos pájaros, venados, liebres, etc. $Y$ lo mejor que hallamos fueron infalibles indicios de mucho gentio y de muchas almas, como eran las muchas y grandes rancherias, frescas lumbres, muchisimos metates, etcétera (Burrus, 1964:230).

Los naturales de estos reales y rancherías de San Bruno y San Ysidro y muchos de las rancherías circunvecinas de San Juan, de San Dionisio, de San Xavier (Burrus, 1964:276). 
Que es tierra más fría y hay junto a dicho río muchas rancherías y muhísimas almas (Burrus, 1964:277).

Y bajando a la ensenada de San Dionisio, caminaron como 20 leguas bacia el sur, y ballaron muchas rancherías con mucha gente bien agestada, mansa, dócil, afable (Burrus, 1964:294).

Las más de estas rancherías hablan la lengua eduana y algunos la lengua nube de los guimes: y muchos, la una y la otra (Burrus, 1964:295).

Hallóse en esta entrada que los destas rancherías tenian mejores habitaciones y casitas que hasta ora en todo lo demás se ha visto, aunque los de la balandra que ahora 20 meses pasaron cerca del cabo de S. Lucas dicen vieron por allá algunas casitas de buen porte y más bien hechas (Burrus, 1964:295-296. Subrayado nuestro).

Las rancherías de 30 leguas que, en su distrito, se hallaron de ida se llamaron: 1, San Sereno; 2, La Concepción; 3, San Simón; 4, Los Mártires del Japón; 5, Santa Agata; 6, San Pedro; 7, San Matías; 8, San Ignacio; 9, San Francisco Xavier; 10, San Valer; 11, San Francisco de Borja; 12, San Agustín; 13, San Nicolás de Tolentino; 14, San Gerónimo (Burrus, 1964:296).

Y a este nuevo pueblo y nueva misión de Nuestra Señora de los Dolores vinieron también a la dicha solemnidad y fiesta cinco gobernadores de las principales rancherías de la tierra adentro (Burrus. 1964:343).

\section{Salvatierra (1857) por su parte señala:}

Desde la rancheria en que vivían los indios, distantes como tres tiros de arcabuz [del real de Loreto] (1857:21).

Un día a mediados de diciembre, pasando por una ranchería distante como menos de cuarto de legua del real [de] estas rancherías en que nos hallamos (1857:26).

A la noche, al tocar las ánimas, una de las juntas o rancherías que no estaba distante dio en alar el alarido (1857:27).

Convidáronlo [a un aborígen que se había ido a la misión y que estaba a punto de morir] algunos para que saliese para la ranchería a recibir sus ceremonias gentillicas (1857:41).

Cuando de repente se nos fue retirando toda la gente de su rancheria para otra parte (1857:42).

Y como a las nueve llegó el embajador a decirnos que pocos días antes parte de la ranchería había ido a pescar a la mar, y la otra parte había ido por no sé que parte de frutilla a una ladera de la Giganta amén que llaman los monqui. meunqui y los cuchimi llaman Medecil (1857:56). El capitán D. Luis Tortolero y Torre y ocho soldados a caballo fueron a una ranchería distante de aquí dos leguas y media con aguajes y cañada de Vhonci (1857:60). 
$\mathrm{Y}$ tres leguas de aquí fueron asaltados de algunos monquies de la ranchería de Vhonci y de la ranchería de Nienchu (1857:60).

Con esto rindieron los de la ranchería de Menchú (1857:65).

Luego salieron todos con armas diciendo que íban a la vista de la isla de Coronados para defender a los pescadores de su ranchería, a quien los enemigos querían matar cuando volviesen en sus canoas de la isla para tierra firme (1857:69).

$\mathrm{Y}$ una hora antes de amanecer el domingo, desde la ranchería distante como dos tiros de arcabuz (1857:70).

Los indios que habían venido de la otra ranchería con nosotros, aunque emparentados con los cuchimies, estuvieron toda la noche en vela con mucho miedo (1857:70).

Salieron a inmediaciones de la ranchería unos indios al encuentro y recibimiento del padre y a los nuestros con demostraciones de gozo (1857:78),

Un indio de la ranchería de Londo nos entregó un caballo, que dos meses habíamos dejado alli medio muerto ya bueno y gordo, siendo así que había ido el indio en él a varias partes a mostrarlo a varias rancherías de su parcialidad, y esto nos pareció en Californias un milagro de bondad (1857:81).

Los monquies que venían con nosotros habían estado en baile toda la noche con hombres y mujeres de la ranchería de Londo de nación cuchimies; había mucha gente rancheada en varios ranchos de la gruesa ranchería de San Juan, de San Bruno y otras muchas rancherías de la Giganta, serranos que llaman laymones y no acudían muchos a la doctrina (1857:82).

El tiempo de las pitahayas, que en este año de 1770 (sic) fue muy temprana y empezó por mayo. Es de saber que los tres meses de la pitahaya son como en algunas tierras de Europa los tiempos de carnestolendas, en que en buena parte salen de sí los hombres; así estos naturales salen de sí, entregándose del todo a sus fiestas, bailes, convites de rancherías distantes y sus géneros de comidas y bufonadas que hacen (1857:96).

Salió el padre Francisco María Piccolo de Loreto acompañado del alférez y otros soldados y subieron a la nueva reducción de San Javier Biaundo por Pascua de reyes, tiempo más riguroso del año; y fue tanto el gentío de rancherías comarcanas de las serranías, que aseguran todos los españoles no haber visto entre indios más número de gente junta (1857:109).

Tercero, se logró la amistad de un cacique que llamaron Leopoldo, que convidó al padre para su ranchería, avisando que tenía aún mayores tierras para sembrar y poblar que ni las de Biaundo; lo cual no se pudo ejecutar entonces y pudo, después de algunos meses, ir dicho padre recibido con mucho gusto de esta ranchería, que queda al 
sur de Biaundo, en donde reconocieron arroyo perenne y tierras buenas (1857:109).

Piccolo (1962), por su parte dice:

Viven en rancherias gruesas (1962:141),

Ellos mismos nos convidaban para sus tierras y rancherías (1962:50). Y con estas salidas descubrió el P. Rector Juan María todas las rancherías de que consta la misión de Loreto Concho y San Juan de Londo; y yo descubrí la misión de San Francisco Xavier Biaundo, que me abrió puerta para pasar a la contracosta, y descubrir todas las rancberías que en su lugar van expresadas (1962:51).

$\mathrm{Y}$, alabando yo las tierras que vimos por el camino, me dijeron los indios que las tierras buenas, con aguas, están donde viven los indios; porque en el camino, no hay ni rancherías ni tierras buenas (1962:156).

$\mathrm{Y}$ a las siete leguas, nos quedamos en la ranchería de Takael, para que comieran las bestias algo (1962:166).

El otro día [12 de junio], pregunté al indio principal si había cerca otras rancherías. Dijome que sí. Y le rogué me llamara a los principales de las rancherías que pertenecían a Kaelmet; pues deseaba verlos, y que no vinieran más que dos o tres de cada ranchería, porque me hallaba con poco bastimento (1962:167).

El sábado [15 de junio], aunque podíamos llegar a la contracosta, nos hicieron parar en un puesto muy hermoso, ameno y cómodo, que le pusimos el púlpito de San Torcuato. El domingo, después de misa, salimos y, antes de mediodía, en un paraje que llaman Kaelsinaheigo, y le pusimos el Ángel de la Guarda, hallamos otra ranchería. Pregunté, y era la ranchería que vive a la playa, donde desemboca el río, y que había salido para juntar sus semillas. Con todo, les dije que yo quería ver la mar. Y porque pensaron que habiamos de dormir en la playa, nos acompañaron muchos de los indios de esta ranchería, con sus redes e instrumentos de pescar. Y cuando supieron que, por amor de las bestias, nos habíamos de volver a hacer noche en el paraje del Ângel de la Guarda, fueron unos de ellos a pescar, y nos dejaron en un teatro digno de admiración, donde se ve claramente como se va desanchando la Califomia hacia el norte (1962:168-169).

Los indios principales por donde habíamos de pasar, nos venían a encontrar para recibimos en sus rancherías, como si fuera gente conocida y avisada de muchos días antes (1962:168).

A la vuelta, se fueron quedando, cada cual en su ranchería o jurisdicción (1962:176).

Asf, por este conjunto de referencias, podemos afirmar que cuando se hace mención a una ranchería se está designando lo que podemos llamar 
una familia extensa, que acampa en un sitio a lo largo de una estación del ano natural. Dicha familia extensa se relacionaba y estaba emparentada con otras que acampaban a "competente" distancia de ella, y así sucesivamente. Dicho conjunto de familias extensas - unificadas por la lengua y los usos, costumbres, adomos, creencias - así como sus campamentos cambiaban con el cambio de estaciones anuales, ya fuese hacia la sierra 0 la costa, según el caso $\mathrm{y}$, como queda referido por la información que hemos citado, sin que ello excluyera el movimiento temporal de un determinado número de familias hacia otras áreas en busca de otros nlimentos que no se encontraban en los contornos de los campamentos temporales.

$\mathrm{Si}$ esto fuese cierto, tendríamos que establecer la normatividad que reglamentaba los asentamientos temporales así como las delimitaciones de los recorridos para el uso y explotación de los recursos naturales del entomo de lo que serian una nación, una tribu, un clan o una familia extensa. Pero llegar a ello es difícil, sobre todo en una forma asertiva, dado cl nivel de información que poseemos. Por ello sólo podemos concluir, por las descripciones de los primeros jesuitas, los siguientes dos principios: 1) Ninguna familia extensa acampaba en los terrenos contiguos o muy proximos a los aguajes o manantiales, sobre todo en los lugares donde no abundaban o no había una corriente perenne, Los campamentos, asi, se localizan a distancia "competente" de los aguajes o manantiales, con el posible propósito de que ninguna familia extensa terminase apropiándose de tal vital recurso. Dependiendo de las necesidades de las familias, éstas llegaban a los aguajes o manantiales para satisfacer sus necesidades, sin que ninguna de ellas gozase de su posesión y explotación exclusiva y exhaustiva. 2) Es más difícil hacer una conjetura especiffica sobre el aprovechamiento de otros recursos naturales $\mathrm{y}$, con ello, de los recorridos que hacian las distintas familias extensas con el fin de explotar las piezas de caza, pesca o recolección de frutos de un territorio determinado, durante un periodo específico del año natural, dado que sólo poseemos la indicación de que las familias extensas movían sus campamentos hacia otras regiones en determinados momentos del ciclo natural, para aprovechar otros recursos, al tiempo que otras familias se dirigían a esos territorios en busca de los recursos que allf se localizaban.

Pero no podemos pensar, por lo señalado en páginas anteriores, que los recursos naturales fuesen tan escasos como para no permitir su aprovechamiento por el conjunto de familias extensas asentadas temporalmente en una región; más que guiarse por una explotación exhaustiva, como han señalado algunos historiadores, las familias parecen comportarse, como en el caso del agua, mediante una explotación mesurada tanto 
para mantener los recursos naturales en su reproducción natural como para limitar, al mismo tiempo, la posibilidad de posesión exclusiva que, en última instancia, hubiera puesto en riesgo al conjunto de familias extensas. En general, puede decirse que los cataclismos y hambrumas se derivaban más bien de causas naturales, que estaban más allá del comportamiento del consumo comunal pues este debió adecuarse a la posibilidad de tales cataclismos y escaseces naturales. Asf, el aprovechamiento y la explotación de los recursos debió corresponder a una normatividad impuesta no por una sola familia extensa, sino por un buen número de ellas y cuya transgresión, no en el orden territorial por si mismo (cosa que no tendría ningún sentido ), sino en el de los usos y costumbres ligados al consumo de los recursos naturales, podría ocasionar enfrentamientos. No obstante, éstos no hubieran de ser tantos ni tan continuos (ni tan "repugnantes"), como después hubiesen querido los jesuitas para asf justificar su conquista y proceso aculturador, pues, de haber sido así, la poblacion total de la peninsula hubiese resultado infinitamente menor que con la que se encontraron, sin considerar asimismo que todos los contactos y relaciones entre unas y otras comunidades, que están referidas en la correspondencia de los jesuitas, carecerían de todo sentido.

Estas dos consideraciones, si bien nos parecen sumamente elementales, son suficientes para planteamos la existencia especifica de tales comunidades y entender sus formas de organización territorial que, sin duda, indican formas mucho más complejas de lo que suele admitirse y sobre las cuales actuaron los jesuitas para sacarle el máximo provecho. Ese fue el caso del movimiento estacional de las rancherías, que les permitió el contacto con otras familias extensas de la sierra o de otras latitudes, sin que se hubiese desplazado de las tierras conquistadas, sobre todo en los primeros meses con la construcción de las primeras misiones. Por otro lado, la existencia de los campamentos temporales (o rancherias) les fue útil a los misioneros para poder organizar, poco a poco, la vida administrativa y misional.

De ello se desprende que los misioneros conocian, asi fuese defectuosamente, la normatividad propia de las comunidades en cuanto al uso y costumbres en el consumo o aprovechamiento de los recursos naturales; valiéndose de tal conocimiento, normaron su criterio de conquista y colonización. Conviene señalar algunos pasos en este sentido. Lo primero que hicieron los misioneros fue apoderarse no sólo de un territorio, sino de uno en que hubiese varios de los recursos naturales indispensables, además de aguajes o manantiales. Asf, la conquista de los territorios forzó y obligó a las comunidades a asistir a ellos. Esta es, sin duda, la principal fuente de contacto entre los invasores y las familias autóctonas. Como se 
uhserva, esta interpretacion se contrapone a aquella que presupone apriorimticamente el estado de mera subsistencia por parte de las comunidades y la actitud caritativa de los misioneros.

Con tales antecedentes podemos explicar el funcionamiento de la institución de los regalos y el trato preferente, que aplicaron primero los hijos de San Ignacio de Loyola y más tarde franciscanos y dominicos, dada In importancia de esas instituciones en la conquista espiritual de las Califomias.

En páginas anteriores hemos expuesto cómo estas instituciones se han vinculado, en el discurso historiográfico jesuítico y projesútico, al paradigma de la pobreza extrema de los Ilamados Californios. Esto ha Inhibido un análisis y una explicación más amplia del proceso de conquista, que en modo alguno puede seguir reducido a los sacrificios y los urabajos que experimentaron los misioneros. Ahora hay que ir más allá. Hay que seguir detenidamente los pasos de los misioneros en su proyecto de examinar usos y costumbres prehispánicos para, finalmente, imponer su propia normatividad a las comunidades sujetas a su "suave yugo".

Desde nuestro punto de vista las instituciones de los regalos y preferencias, que practicaban los misioneros, pudo incidir de manera importante y tener un sentido concreto en la vida de las comunidades debido a que en el mundo prehispánico de las comunidades existían instituciones que, por lo menos en apariencia, correspondran a las establecidas por los misioneros. Algunas referencias citadas no dan lugar a dudas acerca de lo que afimamos. Pero nos resta tan sólo acotar que dichas instituciones entre las comunidades operaba como un medio de intercambio que reforzaba los lazos de equidad y reciprocidad y cuyo fin último era mantener la unión y solidaridad (lo que se llama parentesco) entre las distintas familias nucleares y extensas, clanes, tribus y lo que podriamos llamar naciones.

Los misioneros adoptaron la parte aparente de lo que serfa el intercambio de regalos desde su inserción en las comunidades. En principio, los regalos sirvieron para aminorar la violencia generada con la sola conquista misional de los territorios, aguajes y manantiales de una región determinada. Pues hay que dejar claro desde ahora, a reserva de tratarlo más adelante con el análisis de las fuentes, que dicha conquista fue literalmente militar en términos tácticos. En segundo lugar, el otorgamiento de dones y de trato preferente fue haciéndose selectivo al poco tiempo, lo que origino un grupo compacto y reducido de adeptos en quienes recaía la obligación de abrir las puertas de las comunidades y territorios, desempeñando un doble papel: como maestros de los misioneros para enseñarles a éstos las lenguas, usos, costumbres y el territorio a conquistar, y como predicadores y vigilantes del nuevo orden dentro de sus propias comunidades. 
No podemos dejar de pensar que los misioneros eran conscientes de que sus instituciones de regalos y trato preferente -que sólo posefan un aire de apariencia con las instituciones prehispánicas - terminarian minando las estructuras, los usos y las costumbres de las comunidades a conquistar. Es incuestionable que se provoc 6 el surgimiento de pugnas entre los miembros de las comunidades y que terminarfa en un estado de violencia inusual entre aquellas que estaban siendo conquistadas, y aun entre aquellas otras que ocupaban distintos territorios pero que mantenfan relaciones con las que primero recibieron el influjo de la conquista. Es indudable, asimismo, que esto favorecía a los conquistadores para continuar en sus empeños de someter a todas las comunidades, pues era visible, conforme pasaba el tiempo, el rompimiento de su antigua unidad y su consecuente atomización en distintos niveles.

El reparto de regalos se daba entonces para encubrir el inicio de ta conquista territorial que se estaba llevando a cabo y cuyo elcmento principal, como ya hemos advertido, era el agua. Asi pues, el reparto de regalos se hacfa para paliar o aminorar la propia violencia que generaba el inicio de aquella conquista territorial y que las comunidades podfan interpretar como un acto de despojo y de rompimiento de la normatividad a que habfan estado sujetas. No es descabellado presumir que en un principio la paliación de los regalos y trato preferente se diesen en forma generalizada ya que ello permitía a los conquistadores aminorar, entre el conjunto de las comunidades comarcanas a los aguajes, cualquier tipo de reaccion violenta en su contra, con lo cual su conquista territorial se iba consolidando. Pero conforme pasaron los días y los meses el otorgamiento de dichos regalos debió hacerse menos simple debido a que dichos obsequios comenzaron a vincularse a las conductas que segufan los nativos ante Ios propios misioneros y sus huestes, de lo que resultó la formación de un grupo reducido de seguidores, marcado por un sistema de preferencias.

Por otra parte, resulta más o menos claro que, después de mitigarse un tanto la tensión inicial bajo la cual los conquistadores se apoderaron de los mejores recursos, se hizo extensiva a las comunidades que asistían a los aguajes, la institución del regalo y que, a su vez, se haya comenzado a reglamentar haciéndose más selectiva. Pasados aquellos días, y bajo las nuevas tensiones provocadas por la persistencia de los ignacianos, los regalos y preferencias recayeron sobre quienes encabezaban a los grupos que intentaban amedrentar o resistir a los invasores. Pero los misioneros debian saber que ese hecho poco les podia asegurar alguna ascendencia dentro de las comunidades, ya que justamente la ascendencia de esos individuos dentro de su comunidad residía en la posibilidad de poder resistir y aun expulsar a los invasores, y si ello no lo lograba con tales o 
cuales individuos podía entonces surgir otro cabecilla o líder natural que continuase lo que el anterior no habia hecho.

El conocimiento de esta circunstancia por parte de los jesuitas no les hizo abandonar la estrategía de atracción, incluso cuando sabían que sus logros se reducían a éste, pues las más de las veces el cabecilla cooptado terminaba por ser rechazado en su comunidad, sino excluido totalmente. Pero este resultado poco le interesaba a los jesuitas ya que lo que buscaban, después de apoderarse de un buen territorio, era conseguir a toda costa un reducido y selecto grupo de adeptos que justamente les abrieran las puertas de aquellas comunidades y sus regiones. Esto es, un número selecto de aborígenes que les enseñaran las lenguas, y los principales usos y costumbres, asf como a caminar y encontrar terrenos aptos que además de contar con agua permitieran la agricultura y ganadería.

Pero además de actuar sobre esas personas, los jesuitas pusieron durante los primeros meses especial interés en los niños, mujeres y ancianos, para reforzar a ese selecto grupo que estaban intentando formar, aprovechando su estado de enfermedad o de agonía, bajo el requisito de su real gravedad. En tales situaciones, los jesuitas comenzaron a manifestar su caridad cristiana cubriéndoles el cuerpo con ropa, dándoles atole o pozole - este último muy probablemente con carne-, y algunos alimentos con azúcar y otros productos alimenticios que trafan de la contracosta, acariciándolos afectuosamente y aplicándoles, por último, con la mayor sobriedad, el sacramento del bautismo y los santos oleos. ${ }^{6}$

Con tales actos, Ios jesuitas privilegiaban de por sf a un reducido número de individuos entre la comunidad, si bien esto no duraba más que durante la agonfa del enfermo. Pero el ejemplo estaba dado, sobre todo con los familiaresmás cercanos del agonizante —adulto opárvulo-, a quienes

5 Salvatierra cuenta:

Salió juntamente con nosotros diez hombres un indio cacique, californio y catecímeno, indio adelantado que peleó fuertemente contra nosotros el día de los asal tos y nos dio mucho en que entender por el lado en que el capitaneaba su escuadra, y como peleaba este día con el sol en la cara juzgando que nuestras balas eran como sus flechas que se ven en el aire y en esto atisbaba mucho a ver el fuego y el polvorín para ver las balas en el aire, y como vio que llegaban a herir sin verse cobró mucho miedo a nuestras armas y pacificado no se ha reunido más con los alborotadores; éste, pues, salio, sin armas en compafía de los nuestros (Salvatienta, 1857:36).

Salvatierra cuenta por ejemplo:

...murieron unas tres viejas enemigas de la religion santa que predicamos y del santo bautismo, y no hubo quien avisase a los pactes de su enfermedad siendo asi que sabían muy bien la caridad y limosna que se hacía con todo genero de enfermos de su nación (Salvatierra, 1857:40), 
se les decía que se les aplicaría dicho sacramento y, con ello, el mismo trato en dones y afecto que al ya difunto si seguían las conductas, usos y costumbres que ellos predicaban. Así se iniciaba la cadena de cunversión que terminó mostrando su eficacia, si bien, como veremos, tuvo que vencer rechazos y resistencias por parte de los miembros de las comunidades.

Así, puede pensarse con relativa facilidad que algunos individuos que estuvieron cerca de los moribundos y que vieron los tratos que les dispensaban los ignacianos comenzaron a imitar en palabra y obra lo que decían y hacían los misioneros y soldados para que, con el seguimiento de aquellas actitudes, pudieran ir formando la grey cristiana convirtiéndose en merecedores del sacramento del bautismo y con ello de tratos y obsequios.

Por ello puede afirmarse con certeza que el señalamiento claro y diáfano de a quiénes se les iba a dispensar un buen trato recaía en los individuos que recibían el sacramento del bautismo. Éste identificaba a quienes no sólo eran buenos catecúmenos, como decían los jesuitas, sino a los que se decidían a cumplir y observaban en todo las normas y conductas que imponia la vida cristiana y a cuyas acciones no sólo correspondía la aplicación del sacramento del bautismo sino también de un trato preferente en comida, ropa, afecto. Más aún, se les ofreció tareas especiales dentro de la nueva comunidad cristiana, en la vida misional, y también dentro de su comunidad. Todo lo anterior se convirtió en un ritual público, que atrajo a otros miembros de las comunidades.

Asf́ pues, el bautismo era la más alta distinción que ofrecian los misioneros y, por ello, su aplicación fue restringida a inclusive como dira Salvatierra, postergada aun en aquellos catecúmenos que, pese a su aplicación en el aprendizaje de la doctrina cristiana, se vefan obligados a hacer mayores méritos; esto es, observar fielmente todas las normas y conductas que imponían los misioneros, incluso aquellas que representaban una transgresión a las costumbres prehispánicas.?

Era justamente a través de la impartición cotidiana de la doctrina cristiana como los jesuitas, y más tarde franciscanos y dominicos, explotaron con relativo éxito todo el proceso de "enculturación". Los pasos que

7 Por ejemplo Kino escribía:

Hasta ahora, estos 14 meses que estamos en estos parajes, hemos bautizado cinco naturales; tres párvulos y dos adultos, todos in articulo mortis, y cuatro de ellos pocas horas después del santo bautismo se murieron; el uno vive y está bueno (Burrus, 1964:289).

Es verdad que estos dos años hasta ahora no hemos bautizado más que once naturales, y estos moribundos y de estos once, sanaron los tres (Burrus, 1964:324). 
se tenfan que seguir eran muchos y complejos, pero siempre siguieron un cierto orden, según veremos luego.

Puede resultar más o menos evidente, gracias a la documentación que poseemos, que las primeras prédicas sobre el bautismo eran explícitas en cuanto a que dicho sacramento les abría las puertas del cielo a quienes lo recibían, y aquélos que lo rehusaban eran condenados al infiemo. ${ }^{8} \mathrm{Tal}$ disyuntiva existencial podía resultar incomprensible para los miembros de las comunidades. Sin embargo, puede presumirse que se comenzó a relacionar aquella prédica con la nueva realidad impuesta por la conquista de territorios y aguajes. Asf pues, quienes quisieran ir al cielo tendrian acceso a los dones y buenos tratos de los conquistadores, y aquellos que prefiriesen el camino del infiemo podfan quedar excluidos no sólo de los dones y buenos tratos, sino - lo que podía ser peor-del uso del aguaje y los recursos naturales del entomo que ahora posefan los conquistadores.

Pero esa crudeza siempre podía ser mediatizada y controlada por los propios conquistadores, toda vez que en los primeros meses no se queria que la violencia física traspasase los límites de la intimidación colectiva y

Salvatierra por su parte escribe:

Pocos días antes de la Pascua de Navidad sucedió un tiro de la misericordia de Díos y amparo de la pobladora María Santísima con uno de estos pobres californios, y es de esta manera: antes del día 7 de noviembre, día en que nos dieron el asalto general, asistían con nosotros tres mocitos de a diez y ocho años y nos ayudaban para los menesteres de la casa; el uno de los que me pidió con insistencia que lo bautizara y me rogaron de ello algunos soldados; pero no lo hice para que el catecúmeno se ensefiase más y mejor, supiese la fuerza y obligaciones del santo bautismo (Salvatierra, 1857, 20).

Salida la lancha se empezaron a descubrir otras novedades que mostraban algunos malos efectos de tantas reuniones. Ya por este tiempo empezaban a conocer estas gentes y en su idioma, que el motivo de esta nueva entrada de los espafioles con padres era una nueva religion muy contraria a la antigua que tenian y habian siempre abrazado sus mayores, que los padres ensefiaban esta nueva religión y persuadian a sus gentes que la abrazasen como necesaria para que se salvasen y que entre ellos empezaba a haber tantos de unos que la miraban por bien y de otros que la aborrecían. Ya había muchos que querían bautizarse; pero en reino tan remoto nuevo e inconstante nos pareció a los padres unánimes que todavía era temprano, que se les dijese que primero habían de aprender bien los misterios, artículos y preceptos de nuestra fe (Salvatierra, 1857:31).

'alvatierra dice además:

Nos avisaron del caso, y haciendo las diligencias escondieron el bulto del enfermo [...] Pero lo habia tomado debajo de su amparo la Virgen Santísima, y asf que dentro de tres días lo volvieron a hallar casualmente tres soldados; y así el día siguiente en la doctrina cristiana se les dijo a los indios la importancia del Santo Bautismo, y como los que se mueren sin él no van al cielo, y que era grande el dolor que teníamos cuando algunos enfermos se morian sin el santo bautismo" (Salvatierra, 1857:21). 
el castigo selectivo, especialmente en los individuos que se mostraban más renuentes a la sola intrusión de los conquistadores.

Por lo anterior, es factible pensar que en esos primeros meses no se cerraron completamente las puertas de la misión fortificada, ni se impidió el acceso a los recursos naturales, aun para los aborigenes que no aceptaban la presencia de invasores. Incluso, por los textos de diversas cartas, puede advertirse que se aceptaba a los renuentes y se les daba su ración de comida con el propósito de ir doblegando poco a poco su resistencia, sin señalar en principio una especial dureza de trato. Pero si los resultados no eran alentadores se comenzaba a señalarlos y a hostigarlos para alejarlos del territorio recién conquistado, mientras se procuraba agasajar a los demás para de esta forma aminorar la violencia dirigida contra los renuentes.

Tal sistema comenzo a operar y con ello se inicio el debilitamiento del mundo prehispánico y a cerrarse el mundo misional en tomo a aquéllos que seguian las nuevas formas de vida impuestas por los conquistadores. A medida que esto fue haciendose una realidad estable y duradera, quienes no aceptaban el nuevo estado de cosas huian a los valles intermontaños o a las propias sierras, tratando de evitar el contacto con los conquistadores, aunque no necesariamente con los familiares que habian optado por quedarse en la misión. Este último hecho fue de cierta significación porque posibilito, de una u oura manera, que las prédicas y los usos y costumbres que querían imponer los misioneros alcanzaran, aun en los lugares más reconditos, a los naturales renuentes y que más tarde se tornará en elementos de discordia. En este sentido, y que fue más grave aún, es la dimension que alcanzaron las enfermedades introducidas por los conquistadores y que terminaron imponiendo su cuota en el exterminio de aquellas comunidades.

Todos estos hechos, de muy diversas maneras combinados por las circunstancias especificas de cada grupo, terminaron debilitando y, casi podríamos afirmar, aniquilando a la población nativa.

Debemos plantearnos otro de los paradigmas de la historiografia jesuítica que ha persistido entre los historiadores a lo largo del tiempo. Nos estamos refiriendo justamente a la explicación acerca de la casi total aniquilación de la población nativa. En cualquier sistema interpretativo, este hecho contrasta con los principios que perseguía la conquista espiritual ya que el saldo que arrojó fue la aniquilación casi total de aquellos a quienes justamente se quería redimir tanto en lo material como en lo espiritual. Las explicaciones para entender este resultado pueden ser varias y muy disímbolas. Lo primero es preguntarnos si el sistema misional actuó en la forma que se había propuesto en cuanto a no usar la violencia, las argucias y el encono contra los aborigenes, como lo hab́an predicado Pérez 
we Ribas y Salvatierra. Por los resultados, parecería que los medios de conquista que tanto criticaron las órdenes religiosas estuvieron presentes, ya que se llegó al extremo de casi aniquilar a la población nativa.

Es lógico que los jesuitas y después franciscanos y dominicos rechaaran haber actuado en favor de este hecho; lo mismo piensan sus apologistas, así que el dramático resultado no podría imputárseles a ellos. Por lo cual, la catástrofe demográfica se le imputó a la naturaleza física y humanas de las Califomias. Dichos elementos fueron enunciados a través de la total aridez de la península, su falta de agua y su nula fertilidad; aulemás de un estado permanente de barbarie de las comunidades que incluía un constante nomadismo, una pobreza extrema, una ociosidad permanente y una negligencia cotidiana para adaptarse a la vida que se les querfa imponer. Ignacio del Rfo lo describiría de esta manera:

\begin{abstract}
Como la economia misional se mostrara incapaz [por las condiciones geográficas] de absorber e integrar a la población indigena en su totalidad, los jesuitas establecieron en sus misiones peninsulares un característico modo de funcionamiento, mediante el cual se procuró mantener a todos los neófitos bajo el influjo reiteradamente ejercido de la misión, no obstante que no todos los indios pudieran ser simultáneamente acogidos en los poblados. En los principios de la conquista, los padres se habían propuesto sustentar a todos los indios "que se juntaban en los pueblos, a trueque de que no viviesen vagantes por los montes y pudiesen ser instruidos en la fe"; pero el hecho de que las misiones, aun cuando bubiesen conseguido desarrollar una producción agrícola local, no se dieron abasto para mantener sino a cortos grupos de nativos, demostró con absoluta evidencia que los pueblos formados en la península alcanzaban muy pronto un límite crítico de crecimiento. Los religiosos advirtieron que, de no encontrar un medio de superar esa restricción de origen económico, amplios sectores de la población autóctona permanecerían insumisos y al margen del proceso de evangelización (Del Rio, 1984:135).

[Como, según este punto de vista, terminó sucediendo]. [En] la California jesuítica no se logró la sedentarización plena de la población aborigen, salvo en casos individuales, o en momentos ya tardíos, en los de grupos muy disminuidos (Del Río, 1984:123).
\end{abstract}

Así pues, el fracaso del orden misional no es imputable a la actuación de los jesuitas y su hueste militar, sino al medio geográfico hostil y a las comunidades nómadas que no se supieron integrar al nuevo sistema y que, aún peor, como dice nuestro historiador Ignacio del Rfo:

Habida cuenta de que los californios perdieron gradualmente sus lenguas tradicionales podemos postular que las culturas que ellos 
lograron conformar, desarrollar y conservar por milenios, durante la época de las misiones empezaron a perder, a la vez que rasgos y eficacia, la capacidad de generar una dinámica de autoreproducción (Del Río, 1984:202).

Pero creemos que ésta es justamente la visión que los jesuitas ofrecieron acerca de su empresa evangelizadora y que, como mencionamos, descansa no tanto en pruebas contundentes como en la visión amañada que impulsaron los propios jesuitas, que en general, revelan los prejuicios habituales con que el europeo concibio a las comunidades y grandes sociedades americanas. Una revisión crítica de esa perspectiva, y sus resultados historiográficos, muy posiblemente ofrezcan otra visión y otro tipo de explicación que muy probablemente nos hable, en este caso, de que si hubo un fracaso del orden misional, ello se debio a que las comunidades no aceptaron en principio tan de buena gana a los misioneros ni el nuevo orden que éstos quisieron imponerles. Es decir, que muchas comunidades permanecieron en una constante actitud de resistencia ante los invasores, provocando asf una larga lucha que no sólo enfrentó a los grupos nativos con los conquistadores, sino también a las propias comunidades entre sí, a lo que siguió un periodo de violencia que terminó por desestructurar y aniquilar a buena parte de la población nativa.

\section{BIBLIOGRAFÍA}

ALEGRE, Francisco Javier.1960. Historia de la provincia de la Compantia de Jesús en Nueva España, Edit. de Emesto J. Burrus y Felix Zubillaga, Roma, Institutum Hisoricum, S.J. 4 Vol.

BAEGERT, Juan Jacobo. 1942. Noticias de la península Americana de California. Introd. de Paul Kirchhoff, tr. del alemán, 1a. ed. española. Antigua Librería Robledo de José Porrúa e Hijos.

BAYLE, Constantino, 1933. Historia de los descubrimientos y colonización de los padres de la Compañía de Jesús en la Baja California. Madrid, Libreria General de Victoriano Suárez. (Biblioteca de los americanistas 6).

BURRUS, Emest J. S.J. (Ed.) 1964. Correspondencia del P. Eusebio Francisco Kino con la duquesa de Aveiro y otros documentos, Ediciones José Pomúa Turanzas, Madrid, (Colección Chimalistac, 18 ). 
CLAVIJERO, Francisco Xavier. 1970. Historia de la Antigua o Baja California, estudio preliminar Miguel León-Portilla, México, Editorial Porrúa (Sepan Cuentos, 143).

DECORME, Gerard. 1941. La obra de los jesuitas mexicanos, durante la época colonial (1572-1767), México, antigua librería de José Porrúa e hijos.

DEL RfO, Ignacio. 1984. Conquista y aculturación en la California Jesuítica, 1697-1768, México, UNAM.

MARTINEZ, Pablo L. 1991. Historia de Baja California. Consejo Editorial del Gobierno del Estado BCS, Secretaria de Bienestar Social, México.

PÉREZ DE RIBAS, Andrés. 1992. Historia de los triunfos de nuestra santa fe entre gentes las más bárbaras, y fieras del nuevo orbe: conseguidas por los soldados de la milicia de la Compañía de Jesús en las misiones de la Provincia de Nueva España, refiérense asi mismo las costumbres, ritos, y supersticiones que usaban estas gentes: sus puestos, y temples. Las victorias que de algunas de ellas alcanzaron con las armas los católicos españoles, cuando les obligaron a tomarlas. $Y$ las dichosas muertes de veinte religiosos de la Compañía, que varios puestos, y a manos de varias naciones, dieron sus vidas por la predicación del Santo Evangelio. Ed. Facsimilar, estudio introductorio, notas y apéndice de Ignacio Guzmán Betancourt, México, Siglo xxI editores.

PICCOLO, F. Francisco Marfa, S.J. 1962. Informe del estado de la nueva cristianidad de California, 1702 Y Otros Documentos, edición, estudio y notas por Emest J. Burrus, S.J., Madrid Ediciones, José Porrúa Turanzas.

SALVATIERRA, Juan María. 1857. Documentos para la historia de México. Cuarta serie, México, Imprenta de Vicente García Torres, Tomo V.

TARAVAL, Sigismundo, "Historia de las misiones jesuitas en la California Baja, desde su establecimiento hasta 1737" (obra manuscrita), Biblioteca Newberry de Chicago, (Colección Ayer) Ms. 29873. En: Ignacio del Río. 1984. Conquista y aculturación en la Califormia jesuítica, 1697-1768, México, UNAM, 1984. 